\title{
Study on Moses Hess' Socialist Thought and Its Historical Significance
}

\author{
Wenyi Liu ${ }^{1, *}$ \\ ${ }^{1}$ School of Marxism, Jinan University, Guangzhou, Guangdong 510632, China \\ ${ }^{*}$ Corresponding author.Email: jdsklwy@163.com
}

\begin{abstract}
Moses Hess' socialist thought has been "ignored" for a long time. As a result, when people study the internal opportunities of Marxist socialist turn, it is found that there are deep "cracks" in it. In fact, Hess' socialist thought has rich connotations and has gone through the four stages of theological, philosophical, economic and ethical socialism. It has not only opened the prelude to the spread of socialism in Germany, but also directly heralded the birth of Marx's "scientific socialism". Therefore, it is a valuable topic to explore the evolution of Hess' socialist thought and its historical significance.
\end{abstract}

Keywords: Socialism, Alienation, Relationship.

\section{INTRODUCTION}

Moses Hess' socialist thought was formed and developed in this period from 1930s to 1940 s. However, when people study the history of German or European Socialist Thought in the 19th century, it will be surprised to find that Hess is rarely known. When exploring the source of classical Marxist socialist thought, the academic circles often ascribe to the British and French utopian socialists, such as Saint Simon, Fourier and Owen. However, Hess plays an indispensable role in the socialist transformation of Marx. He not only deeply influenced Marx and Engels, but also was the only one who was on the same way to move forward with young Marx and Engels. The absence of Hess led people to find the deep "cracks" in the study of the inherent opportunity of Marxist socialist turn. Hiromatsu Wataru, Japanese scholar, believes that "the biggest reason why the past research did not fill in this crack is to ignore or underestimate the overwhelming influence of Moses Hess, a leading figure in the Rhine Newspaper on the Left Hegelians" [2]. Therefore, in order to grasp the "overall Marxist" and restore Hess' position in the history of modern socialist thought, it is meaningful to make an

*Fund: This article is supported by the preliminary result of the Educational Humanities and Social Sciences Youth Fund Project - "Marxist Thoughts on People's Livelihood from the Perspective of Capital Criticism" (19YJC710045). attempt to study Moses Hess' socialist thought and its historical significance.

\section{MOSES HESS}

Moses Hess was born in 1812 in Bonn, a city on the Rhine River in western Germany, and died in 1875. His father was a Jewish industrialist, and his grandfather was a biblical and devout Jew. As a child, Hess lived with his grandfather and received strict Jewish enlightenment education. In his youth, he came into contact with commerce and industrial production and witnessed the "inhuman" characteristics in the capitalist industrial and commercial world, which had a huge conflict with his Jewish salvation education. Therefore, like young Engels, he refused his father's strong wish that he should inherit the family business, "but went to study philosophy". After the self-study, Hess was familiar with Rousseau, Hegel, especially Spinoza" [3]. Later, he went to England, Holland, France and other places to live a wandering life. In Paris, France, he came into contact with the utopian socialist works of Babeuf, Saint Simon, and Fourier, and soon became their "believer" and determined to fight for the liberation of individuals and society. Hess' marriage is full of good stories, and he is deeply dissatisfied with the exploitation of the bourgeoisie. "He insists on breaking with the family with Orthodox Judaism, so as to make up for the family's crimes against society. Even he marries 
the prostitute, and has a happy marriage until the end of his life" [4].

Koichi Hata, a Japanese scholar, summed up his life in two parts. "Ideologically and theoretically, he devoted the first half of his life to socialism and the second half to the Zionist movement." [1] ${ }^{276}$ That is to say, from the 1930s to the end of the 1840s, Hess has been struggling for his socialist ideal and wrote a lot of socialist works. Around 1848, he alienated from Marx and Engels, and began to devote himself to the Zionist movement. Finally, he won the title of "Communist Rabbi".

\section{THE EVOLUTION OF HESS SOCIALIST THOUGHT}

In the analysis of Hess' philosophy, "there is no unity in Hess' philosophy, and it is futile if you want to find the system or coherence of his philosophy," said Sydney Hook, an American thinker. He is a Spinozist, Hegelian, Feuerbach, Marxist, natural scientist and the synthesis of the above [4]. In fact, a philosopher is inseparable from a socialist. With the change of his philosophy, his socialist thought has undergone a leap-off transformation, which can be divided into four stages: theological socialism, philosophical socialism, economic socialism and ethical socialism.

\section{1 "Theological" Socialism}

The so-called "God" refers to "the law of nature". Hess inherited the French enlightenment thought in the early years, emphasizing the sanctity of the "natural law". In the preface to "the holy history of mankind", Hess said: "as the time goes by, the understanding of God has been confused. People's understanding of this God has been lost." $[1]^{2}$ It is believed that Hess' "God" refers to the medieval personality. In fact, Hess is on the position of "natural law" to expound his socialist vision. This is clearly reflected in the subsequent argument. "The divine God tells mankind that to seek the nature is to abide by the eternal law, and it is necessary not to attempt to fight the law of nature and God fruitlessly." [1] $]^{74}$ From here, Hess uses the "nature" or "law of nature" in the same sense as "God" or "the law of God". Combined with young Hess' admiration for Rousseau, Spinoza and other deists, it can conclude that Hess' "God" refers to "natural God". The reason why Hess expressed his socialist appeal in the way of "theology" in "the holy history of mankind" is partly due to the author's mental and psychological confusion, and partly due to his worry about the censorship system and the need to avoid causing political trouble. [5]

Starting from the "natural law" and the "freedom, Hess regards absolute spiritual freedom as the essential feature of socialism, and "holy history" is the history of free activities. According to the text structure of "the holy history of mankind", Hess unfolds the process of human spirit moving from unconsciousness to selfconsciousness according to the "law" of the development of the Holy Father, Holy Son and Holy Spirit. The "Holy Father" stage refers to an unconscious harmonious or undifferentiated stage between human spirit and "God", which is the unfree stage of human spirit. The stage of "Holy Son" refers to the stage of division or struggle between human spirit and "God", which is the transitional stage of human spirit from unconsciousness to consciousness. The "Holy Spirit" stage refers to the conscious unity stage of human spirit and "God", and the stage of human spirit's free activity.

According to "the holy history of human beings", the process of human spirit moving towards absolute freedom is a process of "natural" movement in strict accordance with the "natural law". And all living things, consciously or unconsciously, are striving towards "perfection". In Hess's words, nature has given the seeds of this degeneration, and also endowed with the peculiar character that people have to dispel the selfcontradiction people fall into. With the return of "freedom", all social inequalities will disappear. In the face of this "natural" law of freedom, what can man do?

Hess' prescription at this time is "inaction", that is, "human freedom does not lie in human arbitrariness, but in the conscious obedience to God's law" $[1]^{7}$. And any way to resort to radical activities or violence for freedom is not the right way to enter the ideal society. Obedience is the absolute principle. As the representative of the national will, the government should "coordinate" and mediate the inevitable "conflict" or "inequality" in the "divisive period" in a timely manner, so as to ensure a peaceful transition to an ideal society of 
public property, absolute freedom and equality "the New Jerusalem or the Kingdom of God." In his early days, Hess tried to find a theoretical base for his socialist ideal through the "God of nature", but it was full of mysterious and enlightening religious color. Therefore, his socialist thought is called "theological" socialism.

\section{2 "Philosophical" Socialism}

Around 1840, Hess began to pay attention to the philosophy of Hegel and young left-school Hegel. The "sense of reality" of Hegelianism and the upsurge of left-school Hegel's real "action" cater to Hess' deep and realistic feelings of social salvation. However, the completely abstract belief in "natural law" is incompatible with his philosophical thoughts at this time, which leads Hess to give up the "theological" expression of socialist theory and demonstrate and develop his socialist theory from the "philosophy of action". The initiator of "philosophy of action" is Ceszkowski, a Polish philosopher. In his pamphlet "introduction to philosophy of history" (1838), he said that "to replace speculative philosophy with philosophy that brings practical activities into its scope ... people must use this kind of knowledge to change the future world". [6] Under the influence of Ceszkowski's "philosophy of action", in 1841, Hess wrote the book "triumvirate in Europe" (hereinafter referred to as "triumvirate"), which is the first step to demonstrate the necessity of socialism from the philosophical level.

In the "triumvirate", "freedom" is still the core concept of his socialist thought, but the "freedom" here is not the pure spiritual freedom in the early stage, but the "positive freedom" constructed by the "philosophy of action". Because "spiritual freedom can be positive freedom only when it is organically integrated with the freedom of action and reality $[1]^{26}$. "Positive freedom" is no longer to comply with "natural law", but freedom is to obtain through "self-determination".

Hess thinks that in order to win this kind of freedom, theoretically, it is necessary to derive the future from the past and the existing, and bring it into the field of speculation. In practice, the alliance of Germany, France and Britain is regarded as the ideal state of the future society. In the subsequent political review of "Rhine Newspaper" and "the twenty-one prints from Switzerland" (hereinafter referred to as the twenty-one prints), Hess made a more detailed argument. He believed that the most urgent problems in Germany and France are the disparity between the rich and the poor and the sharp opposition between money aristocracy and extreme poverty. These problems are not political problems, but social problems, which can only be solved through social change. Political liberation can only enable people to obtain "abstract human rights, which is just another form of slavery" $[1]^{94}$. However, the path of social change is only "German-French Union". Germany represents the highest level of spiritual freedom in the world, while France represents the commanding height of social freedom. Only in the organic combination of the two, "real freedom" is possible. How is this kind of union possible?

From Spinoza's ethics, Hess found the future principle of this connection - the absolute unity of all life. Spiritual freedom and social freedom are the two complementary elements of this basic principle. Hess believes that this principle has been completely quietly unfolded on both sides of the Rhine - Germany and France. In Germany, Feichter was the pioneer of atheism in the field of spirit. Since Schelling and Hegel, the influence of atheism began to spread to real life. In France, Babeuf is the pioneer of communism in the social field. Since Saint Simon and Fourier, the Communist thought began to penetrate into the masses. That is to say, the two have the tendency of re-unification in action. The task is to promote this unity through the philosophy of action, which is the "free community". Hess pushed the communism of philosophy to the extreme, and in this sense, Engels commented that "Hess was the first person to achieve communism through philosophy." [6] ${ }^{156}$

\section{3 "Economic" Socialism}

It was inspired by Feuerbach that Hess turned to "economic" socialism. According to the research of Japanese scholar's conscience, "Hess was really influenced by Feuerbach from the early days (partly from the "Rhine Newspaper"), especially since the "German-French Yearbook", Hess's thought even turned into the" Feuerbach stage ". [1] ${ }^{256}$ Inspired by Feuerbach's criticism of Christianity through alienation theory, Hess creatively applied alienation theory to the analysis of capitalist social and economic life in his article "on the essence of 
money", and he was "the first one among the Young Hegelians to deeply explore more fundamental economic phenomena in his view". $[6]^{164}$

In the article "on the essence of money", Hess regards human nature as "quasi life" or "social communication", and thinks that "social communication" is like the "atmosphere" for individual survival, without which individual will not survive. In the modern business world, the individual lives in the double alienation state of "social interaction", which is God in heaven and money on earth. Compared with religion, money embodies human alienation. It should be the general means of exchange and the intermediary of life. Under the logic of capital, it becomes "the essence of the state" and "the sacred legislator", while the individual becomes "the holder of the purse" and "the abstract personality". The purse is the standard of everything. In this alienated life, people's freedom and life are "sold off" in various forms, and they enjoy each other's life in a cruel and cannibal way. The quasi and individual are in an irreconcilable confrontation.

How can people get rid of this alienated "quasi life" - money? Hess believes that alienation and the sublation of alienation show the same historical process, that is, the alienated life is the generation stage that the unfinished individual must go through. "Through this abstraction divorced from reality, spiritual and living communication, human ability and productivity are enhanced when human alienation occurs". [1] ${ }^{164}$ With the improvement of individual production capacity to a certain extent, "we are subject to the internal necessity of our own nature and the external needs of our relationship. We will unite into a community, take all external means of communication, uproot all our flesh stabs as alien bodies, and wipe out the inhuman phenomena and despicable activities in capitalist society forever." [1] ${ }^{165}$ As the natural or generative history of human society ends, it is required to enter a state of harmonious unity of individual and "quasi" - communism. On the contrary, if people have developed their capabilities without a transition to communism, "people can only exploit and devour each other more severely." [1] $]^{166}$

So, in what way did the developed individuals unite and make the transition to communism? Hess believes that love is the fundamental way of union, and the emphasis on love makes his socialist thought slide to the horizon of ethics.

\section{4 "Ethical" Socialism}

According to Hess, the "ethical" and "real" have the same meaning, "ethical" socialism is also "real" socialism. This socialist theory is based on "supraclass" and "abstract" human as its starting point. It is a reformed Feuerbach's humanitarianism. Its essential feature is that it regards love as the foundation of future society and the most important factor in human nature.

In fact, due to the influence of Spinoza's moral philosophy, Hess' socialist theory has always been permeated with ethical love. In "the holy history of mankind", absolute obedience to God is called "goodness". In the period of philosophical socialism, Hess believed that the reason why German philosophy could not transit from speculative field to "action" was due to the lack of love. In demonstrating the socialism of economics, he took love as the bond of individual Union.

The real development of Hess's "ethical" socialism is in his later works, such as "the question and answer of the Communist creed (1844)", "the speech on Communism (1845)" and "the last philosopher (1845)". In these articles, the activity of obtaining "true freedom" is still the basic principle of his exploration of human liberation, and he thinks that it is "the activity driven by the heart" $[1]^{169}$. However, this kind of free activity cannot be realized in capitalist society, because the logic of capitalist production is that money is omnipotent and there is only compulsory labor. In order to abolish these, it can't pass any laws. It is suggested to build a communist society through love. Love regulates everything here. "When we no longer live in selfishness and hatred, but in love, in a harmonious environment, and in communism, we gain heaven on earth." [1] ${ }^{178-179}$ The inhuman labor based on violent plunder, slavery, irrationality and injustice will no longer exist. Instead, it will be a comfortable, free and humane "real" life.

When it comes to the realization of communism, Hess insists on reformism. It is believed that as long as the capitalist society is aware of its predicament and the trend of being replaced by a better society, and people are stimulated to get rid of slavery and yearn for a life 
in line with the human society, it's going to be a gradual transition to socialism. On the contrary, "to abolish the current ownership by means of violence and surprise attack will inevitably lead to adverse consequences." [1] ${ }^{176}$ And only through education, their various social characteristics can play a role in social life, and get social recognition. "Only when an individual realizes his own ownership, his own can become the real ownership." [1] $]^{196}$ The real human society will be organized consciously according to human nature - love.

\section{THE HISTORICAL SIGNIFICANCE OF HESS' SOCIALIST THOUGHT}

\subsection{Opening the Prelude of German Socialist Communication}

In the study of German Socialist pioneers, people often take Wihelm Weitling as the most important representative. In fact, Hess was also one of the first leaders in Germany to actively spread communism. In 1837, Hess wrote "the holy history of human beings", one year earlier than Weitling's masterpiece "realistic human and ideal human (1838)".

"The holy history of mankind", a socialist work full of prophecy and admonition, did not cause much repercussion at that time, but it was quite important. For the first time, Hess tried to combine German philosophy with French socialist materials to express a socialist ideal of eradicating social inequality and realizing human liberation. It is one of the most important early documents to study the history of German Socialist thought, and opens up the way for the spread of socialist thought in Germany. As a result, Jonathan Frankel, the British scholar, called Hess a miracle in the history of German Socialist thought. He was not only the father of radical socialism in Germany, but also the Zionist that is most worth mentioning today [7]. Different from "the holy history of mankind", the publication of "triumvirate" of Europe (1841) attracted the attention of his contemporaries. "The reason why the title of the book was adopted was to be opposite to a book published at that time called "pentarchy in Europe", which advocated the alliance among Russia, Austria, Putin, France and Britain. On the contrary, Hess advocated that Prussia should form an exclusive alliance with
Britain and France." [6] ${ }^{148}$ Like Saint Simon, Hess proposed the establishment of "triangle alliance" among Germany, France and Britain as the rudiment of new European socialism in the future. Different from the blind tool of regarding the human beings as mysterious spirit in "the holy history to human beings", "the pentarchy in European" takes the autonomous action of human beings, namely, "philosophy of action", as the central theme of the work, which clearly combines Hegelian philosophy with French socialism and runs through a series of later works. In the beginning, the Young Hegelians were not interested in their socialism, but favored their "philosophy of action", because Hess' "philosophy of action" catered to their needs of critical philosophy. Later, with the Prussian King's extreme autocracy in politics, the Young Hegelians' radical political liberalism was suppressed. In the confusion of theory and reality, they accepted Hess' socialist thought one after another, which won Hess a high reputation. For a while (1842-1843) in Germany, socialism or communism became fashionable. In September 1844, under the encouragement of Hess, the Communist club was established and some "real socialism" theories were developed under his leadership. From 1845 to 1848 , it became a socialist thought widely spread in Germany, and was criticized by Marx as "a real disease of flow". However, Hess has made an indelible contribution to the spread of socialism in Germany.

\subsection{Indicating the Birth of Scientific Socialism}

In the article "on the essence of money", when discussing the motive force of social and historical development, Hess has tried to explore from the conflict between man's productive capacity and "communication relationship".

Hess called individual productive capacity as "productivity" and "social communication" as "communication relationship". It is believed that "The more people interact with each other, the more productive they become." [1] $]^{139}$ When people's productive capacity is strong to a certain extent, it is necessary to change the "communication relationship" and enter the Communist society. Otherwise, it will result in "mutual destruction", "unproductive waste" and "stagnation of productivity". [1] ${ }^{166}$ It is obvious that Hess has 
vaguely expressed the basic principle of historical materialism, that is, the contradictory movement between "productive forces" and "communicative relations". No matter from the basic point of view or the use of terms, Marx's classic exposition of historical materialism in "German Ideology" is undoubtedly further developed along the "preliminary expression" of Hess.

McClellan has noticed the genius of Hess. He said: "the first section of 'on the essence of money' discusses the origin and development of trade and commerce from the natural and social results, which reminds people of the earliest famous conclusion about historical materialism at the beginning of 'German Ideology'. In the next section, Hess' argument that 'the only basis of thought and activity is trade and cooperation between individuals' has predicted Marx's theory on the relationship between foundation and superstructure and his concept of ideology." [6] ${ }^{167}$ This shows that the scientific socialism thought based on historical materialism has sprouted in Hess' socialism theory.

However, Hess' socialist theory still represents a kind of immature socialism. "He turned to socialism before Marx and Engels, but he never or only half-heartedly broke with philosophy. He never got rid of the remnants of idealism which caused new friction and discord." [8] It means that in his exploration of socialist thought, he cannot go beyond the barriers of early utopian socialism. In any case, Hess has begun to explain the inevitability of socialism from the objective facts of social and economic development itself and the fundamental driving force of social development, paving the way for the inevitable birth of Marx's scientific socialism theory.

\section{CONCLUSION}

To sum up, Hess's socialist thought is still in the immature stage. However, his active exploration of ideal socialism not only opened the prelude of the spread of socialism in Germany, but also directly predicted the birth of Marx's "scientific socialism".

\section{AUTHORS' CONTRIBUTIONS}

This paper is independently completed by Wenyi Liu.

\section{REFERENCES}

[1] [Germany] Moses Hess. "Moses Hess: Selected Writings", translated by Deng Xiyi, Nanjing University Press, 2010, preface, p. 4. (in Chinese)

[2] [Japanese] Hiromatsu Wataru. "The Original Image of Historical Materialism", translated by Deng Xiyi, Nanjing, Nanjing University Press, 2009, p. 154-155. (in Chinese)

[3] [French] Auguste Cornu. "The Story of Marx and Engels" (Volume 1), translated by Liu Pikun and others, Beijing, Life•Reading•Xinzhi Sanlian Bookstore, 1965, p.254. (in Chinese)

[4] Hook, Sydney, "Karl Marx and Moses Hess", New Internatianal, Vol.1. No.5, December 1934,140 .

[5] Avinerl, Shlomo, "Socialism and Judaism in Moses Hess's 'Holy History Mankind", Review of Politics.45:2(1983), 235.

[6] [British] David McClellan. "Young Hegelians and Marx", translated by Xia Weiyi et al., Beijing, The Commercial Press, 1982, p. 11. (in Chinese)

[7] Frankel, Jonathan, "the communist rabbi': Moses Hess", Commentary.41:6(1966), 77.

[8] F. Mehring. "History of the German Social Democratic Party" (Volume 1), translated by Qing Zaifan, Beijing, Sanlian Bookstore, 1973, p. 272-273. (in Chinese) 